\title{
The cost of equity in the energy sector
}

ABSTRACT: Taking the importance of time and risk into account has a significant impact on the value of investment projects. Investments in the energy sector are long-term projects and, as such, are burdened with uncertainty associated with the long-term freezing of capital and obtaining the expected return. In the power industry, this uncertainty is increased by factors specific to the sector, including in particular changes in the political and legal environment and the rapid technological development. In the case of discounted cash flow analysis (DCF), commonly used for assessing the economic efficiency of investments, the only parameter expressing investor uncertainty regarding investment opportunities is the discount rate, which increases with the increasing risk of the project. It determines the value of the current project, thus becoming an important criterion affecting investors' decisions. For this reason, it is of great importance for the assessment of investment effectiveness. This rate, usually in the form of the weighted average cost of capital (WACC), generally includes two elements: the cost of equity capital and borrowed capital. Due to the fluctuant relationship between these two parameters in project financing, performing a WACC analysis in order to compare the risks associated with the different technologies is not completely justified. A good solution to the problem is to use the cost of equity. This article focuses on the analysis of this cost as a measure of risk related to energy investments in the United States, Europe and worldwide.

KEYWORDS: investments in energy, risk, cost of equity, discount rate adjusted for risk

\footnotetext{
${ }^{1}$ AGH University of Science and Technology, the Faculty of Management, Kraków; e-mail: psalug@zarz.agh.edu.pl

${ }^{2}$ Mineral and Energy Economy Research Institute of Polish Acadamy of Science, Kraków.
} 


\section{Introduction}

Before investing, cash owners must be aware of the fact that there is always more than one way to use their resources on the market. Acting rationally, they should analyze the aforementioned possibilities, taking the cost associated with each choice into account. It is usually referred to as the cost of equity capital and it is directly related to investors' expectations in terms of the rate of return from the considered investment opportunity and is therefore usually expressed as a percentage value.

Therefore, investors make investment decisions depending on the expected or required level of interest rate determined by the risk scale of a given project, which also includes the uncertainty regarding the time required before the expected returns are gained. Generally, the greater the risk for the investor, the higher the expected returns. Without any hope of greater returns, investors would not consider carrying out projects with higher risk levels at all; if their aim would be to minimize the risk or if there were no bonus for the risk, then they would invest in projects with little or no risk (bonds, treasury bills).

In order to assess the economic effectiveness of the projects, investors use a variety of methods, the most widespread of which is the discounted cash flow analysis (DCF). This technique takes the time value of money and uses the cost of capital to update (as of the assessment date) future financial results into account. This cost is the only parameter in the DCF analysis reflecting the risk of the assessed project, as all other ones are treated as expected - the analysis requires them to be risk-free.

Meeting the DCF requirements in this respect is however not trivial. Accurate forecasts of cash flows are required for the expected lifetime of the project; however, investors bear in mind that reality can be totally different from the predictions, especially since the final estimation of the future flows depends on the prediction of individual parameters (price of products, operating costs, capital costs, taxes, exchange rates, economic policy of the country, etc.).

The cost of capital is therefore one of the main parameters of discounting methods determining the effectiveness of the investment. The question of the selection of the discount rate for the assessment of investments in the energy sector has been discussed in Polish literature by Zamasz $(2015,2017)$, whose work became an inspiration for the presented article; in addition, this issue was analyzed by specialists from the Energy Regulatory Office (ERO 2015). The issue of estimating the cost of capital for energy projects is widely discussed in Western literature (e.g. Redpoint 2010; DECC 2011; Stenibach and Staniaszek 2015; Grant Thorton 2018). 


\section{The role of the discount rate in assessing the economic efficiency of energy projects}

The weighted average cost of capital (WACC) is recommended as a discount rate in the DFC analysis. This cost is the weighted average interest rate of the equity capital and borrowed capital, according to the following formula:

$$
W A C C=R_{E} \cdot V_{E}+R_{D}(1-T A X) V_{D}
$$

Where:

$$
\begin{array}{ll}
R_{E}=R A D R & - \text { the cost of equity, } \\
R_{D} & - \text { the cost of debt, } \\
T A X & - \text { corporate income tax rate, } \\
V_{E}, V_{D} & - \text { the share of equity capital }(E) \text { and borrowed capital }(D) \text { in investment } \\
& \text { expenditures }\left(V_{E}=\frac{E}{E+D} ; V_{D}=\frac{D}{E+D}\right) .
\end{array}
$$

In business practice, credit plays a significant role - the rate of interest and the scale of financing have a significant impact on the WACC discount rate. It should be emphasized that the cost of equity (and therefore the risk associated with it) is usually higher than the cost (and risk) of the loan. This stems from the fact that the loan agreement guarantees the bank a profit (interest) and repayment within the set period (in the case of bankruptcy, the bank demands are satisfied first). Private investors providing capital in exchange for shares in the project agree to bear higher risk, as they receive the first dividends from the project only after all financial and tax obligations have been met. Therefore, they naturally expect a higher return on the investment.

In order to make further comparative analyses, the article assumes that all arguments regarding discount rates will refer to investments financed exclusively with equity, including tax calculation.

The cost of equity, due to not taking the uncertainty related to a given investment into account, is also called the risk-adjusted discount rate (RADR) in the literature. In the case of companies listed on the stock exchange, the RADR is determined analytically in the capital asset pricing model (CAPM) according to the following formula:

$$
R_{E}=R A D R=R_{f}+\left(R_{m}-R_{f}\right) \beta
$$

Where:

$R_{E}$ - the cost of equity capital, RADR - the expected return on " $i$ " assets,

$R_{m}-$ the expected return on the market, 
$R_{f}$ - the risk-free rate,

$\beta$ - the beta coefficient for " $i$ " assets.

The risk-free rate, $R_{f}$, calculated based on returns from risk-free securities (treasury bills, bonds). This rate varies with the economic situation and monetary policy.

Beta, which is the product of the correlation coefficient between the rates of return on the discussed shares and the market and the quotient of standard deviations of these rates, determines the risk premium associated with the investment in a given project.

According to the portfolio theory, beta equals unity. If:

1) $\beta>1$, then the rate of return on the company's securities is more variable than the return on the entire market, while if

2) $\beta<; 1-$ then this rate is less variable than the rate of return on the entire market.

The most popular method of estimating the beta coefficient is the calculation using the regression analysis according to the formula (2). Beta coefficients are often published. In relation to the assumed assumption, it should be emphasized that the classic $\beta$, the so-called levered beta, does not refer to the structure of the capital. Therefore, in order to find out what part of the company's risk is associated with the equity, use the Hamada equation:

$$
\beta_{u}=\beta\left[1+(1-T A X) \frac{E}{D}\right]
$$

Where:

$\beta u$ - unlevered beta.

In addition to the above, it should be taken into account that the volatility of share prices and market volatility are not the sole sources of risk for the venture. An important role is also played by the investment climate and the socio-political situation of the country in which the investment is made. Only selected countries (e.g. the US or Canada) are considered free from domestic investment risk; in the case of projects undertaken in politically unstable countries, the cost of capital should be increased by the percentage related to this risk. And therefore, the discount rate $(\mathrm{RADR})^{*}$ can be expressed using the following equation:

$$
r=r a d r=r_{f}+r_{s}+r_{c}
$$

\footnotetext{
* It was assumed that symbols expressing current (nominal) amounts are presented in capitals, while fixed (real) ones are represented by a small letter; conversion of the real discount rate into the nominal rate is carried out using the
} Fisher formula:

$$
1+R=(1+r)(1+i)
$$

Where:

$i$ - the rate of inflation. 
Where:

$r$ - the real discount rate (assuming zero inflation),

$r_{f}-$ the real, risk-free, long-term interest rate,

$r_{s}-$ the percentage related to the specific risk of the project,

$r_{c}-$ the percentage related to the domestic investment risk.

In the case of current currency, it also includes the " $i$ " inflation rate.

The specific risk of a project results from the uniqueness of a given project compared to other projects and the related uncertainty; it is usually the largest share within the discount rate.

As mentioned above, the interest rate on securities guaranteed by the state is considered to be the risk-free rate. US Treasury bills (Treasury Bills, T-Bills) and bonds (T-Notes, T-Bonds) are, among others, generally perceived as truly risk-free. The risk-free instruments have zero variance and zero covariance with any other asset or portfolio.

There are several views on the correctness of determining the risk-free rate. It is believed that the rate should be estimated, among others, based on:

1) Interest on safe instruments with lifetimes comparable to the lifetime of the project being assessed; in the case of energy projects with a short lifetime, the basis for determining the risk -free rate should therefore be the interest on short-term government securities - treasury bills or short-term bonds, while in the case of projects with a longer lifetime - returns on long-term securities (bonds);

2) Interest rates long-term instruments; advocates of this approach (Copeland et al. 1997) argue that the rate of return on long-term (ten-year) bonds is less sensitive to unexpected inflation fluctuations;

3) The expected interest on short-term securities (Mayo 1997) regardless of the project duration; the argument for such an approach is, due to the time factor, their greater security; the longterm rate is estimated taking the long-term average return on these short-term assets into account;

4) Yield curve using bootstrapping techniques (Pindred 1995).

The cost of equity calculated in accordance with the formula (2) refers to the risk of the entire enterprise. It should be borne in mind that companies carry out various investment projects each project is characterized by a specific risk. If the risk differs significantly from the risk of the entire company, it is of significance to investors; therefore, it may play an important role in the determination of the feasibility of the project; what is more, the risk of the project may change the total of the company-specific risk. Investors will then require an additional risk premium, which translates into the expectation of a higher rate of return on projects with a higher risk level.

The mentioned aspects are of vital importance in the context of the exponential impact of the cost of capital on the value and economic feasibility of the project. The discount coefficient $(1+R)^{-t}$ (where $t$ is a given investment year) affects the current value of cash flows of an investment in a twofold manner:

- The higher the level of the discount rate, the lower the present value of the investment,

$\checkmark$ In the case of long-term investments, a high discount rate results in low values of cash flows generated in the middle and final years of the project. 
The DCF analysis is based on the assumption that the value of profits received from the same amount of capital invested varies depending on the investment time horizon; therefore it is a reasonable and credible method for the assessment of low-risk and short-term projects. This remark is particularly important in the case of processes of economic evaluation of investment projects implemented in the power sector, for which the pre-production period, which does not generate income, is longer than in other industries. The use of DCF techniques in the processes of assessing such projects is often criticized.

\section{The specificity of investment projects in the power industry}

Investments in energy projects are characterized by a number of specific features that make them different from projects undertaken in other industries. Thus, the first fundamental difference stems from the unique properties of electricity as a product:

$\checkmark$ It is not visible and tangible,

$\downarrow$ It is a homogeneous product with the same parameters regardless of the production method; this means that there is no competition between manufacturers in terms of product quality (small importance of the manufacturer's or seller's brand). Competition takes place mainly at the level of operating costs (fixed and variable) and investment expenditures, which are essentially related to manufacturing technology,

$\checkmark$ The possibilities of its storage are limited, which means that there is a need to constantly balance demand with supply - electricity must be supplied when there is a demand for it,

$\downarrow$ It is a product with a guaranteed demand - it cannot be replaced by another medium in the short term,

$\diamond$ Ease of:

$\downarrow$ transmission (with the reservation that its transmission is limited by network infrastructure),

$\checkmark$ distribution between users and regulations,

$\downarrow$ The possibility to:

$\downarrow$ generate high electric power,

$\downarrow$ of processing into other types of energy, other forms of the same energy, and to electrical signals.

The specificity of electricity as a product is the reason for the uniqueness of the market for this commodity. It is characterized by a different dynamics than other markets (Bartnik 2008).

Other significant characteristics of projects (development of generation capacities) carried out in the energy sector, contributing to the fact that these projects are generally subject to higher risk than investments in other branches of the economy, are characterized below.

The characteristic feature of the discussed investments is their sequential and long-term nature - this applies to both the construction stage and the operation stage (benchmark initial 
(pre-development), construction and operational periods for different production technologies are shown in Table 1). This means that the first returns of capital are often obtained only after many years. In addition to the negative impact on the discount rate, an additional difficulty is the long-term prediction of management conditions and therefore the problem of effective forecasting of energy prices and costs - including fuel prices and emission allowances.

TABLE 1. Estimates of the length of initial, construction, and production periods for various production technologies (central values) (DECC 2013)

TABELA 1. Szacunki długości okresów: wstępnego, budowy i produkcyjnego dla różnych technologii wytwarzania (wartości centralne)

\begin{tabular}{|l|c|c|c|}
\hline \multicolumn{1}{|c|}{ Technology } & $\begin{array}{c}\text { Pre-development } \\
\text { period }\end{array}$ & $\begin{array}{c}\text { Construction } \\
\text { period }\end{array}$ & $\begin{array}{c}\text { Operating } \\
\text { period }\end{array}$ \\
\hline CCGT & 2 & 3 & 25 \\
\hline OCGT & 2 & 5 & 25 \\
\hline Nuclear - FOAK & 5 & 6 & 60 \\
\hline Gas - CCGT with post combustion CCS - FOAK & 5 & 5 & 25 \\
\hline Coal - ASC with oxy combustion CCS - FOAK & 6 & 6 & 25 \\
\hline Coal - IGCC with CCS - FOAK & 5 & 5 & 25 \\
\hline Onshore >5 MW UK & 4 & 2 & 24 \\
\hline Offshore Round 2 & 5 & 3 & 23 \\
\hline Offshore Round 3 & 6 & 3 & 22 \\
\hline Large scale solar PV & 0 & 1 & 25 \\
\hline Biomass conversion & 2 & 1 & 22 \\
\hline
\end{tabular}

It should be emphasized that the long-term pre-production period results from the fact that investors in the sector have to face the development risk (related to the construction stage), which is the risk of delays in the construction process and increased costs of capital resulting from uncertainty about the condition and credibility (competences) of construction companies.

Investments in the energy sector are large-scale, technologically complex and advanced projects and therefore they require huge investment outlays related to the preparation of project documentation, land purchase, granting of approvals and licenses, development of generating units and connecting them to the transmission network. The process of operation of the unit is also capital intensive. Of course, this requires obtaining financial resources; it should be emphasized that in the case of the discussed projects there are difficulties related to both organization and financing. Potential investors increasingly take the view that the price of energy is not a sufficient incentive to freeze funds for such a long time; they believe that the classic energy market may not provide the expected return on investment due to the volatility of prices and the lack of price protection (prohibition of long-term contracts guaranteed by the state), and the risk of oversupply. In addition, investments in the energy sector are basically irreversible - in the case of failure, it is very difficult to recover the greater part of the funds involved (sunk costs). 
In addition to the above, investors must bear in mind the fact that a company producing electricity, due to the need to ensure system security under the conditions set by the state authorities and the operator, has no full freedom in using its own generating capacities. This strongly limits the readiness to invest.

Another specific feature of investments in the energy sector is the need to take limitations regarding the location of generating units into account. The location of units is conditioned by access to the transmission networks at places indicated by the transmission system operator.

An important specificity of projects in the power industry is the dependence of the sector on government policy, legal regulations, and climate policy - in particular emission limits for certain harmful substances and pollutants $\left(\mathrm{CO}_{2}, \mathrm{NO}_{\mathrm{x}}\right.$ and others). These regulations are becoming more and more restrictive - their introduction resulted in, among others, the establishment of the carbon emission trading market. The EU supports the development of renewable energy sources, which naturally contributes to an increase in their share in the power balance and thus increases in the uncertainty regarding the use of conventional energy sources. The announced further emission limits are the reason for an increase in the uncertainty of potential investors, as these modifications will affect, both materially and financially, the functioning of energy companies. In countries like Poland, the uncertainty is additionally intensified by the lack of coherent, longterm government policy, the instability and unpredictability of legal regulations, etc. As a result, potential lenders may require restrictive guarantees and loan collateral from the investors (e.g. securing the loan with all assets).

\section{An analysis of the cost of equity of energy enterprises in the US, Europe, and the world}

As mentioned above, the main elements of the company's equity capital, most often determined in the CAPM model, are the risk-free interest rate and the percentage related to the company-specific risk. The "risk-adjusted" rates of individual projects undertaken by the company cannot be determined in an analytical manner. However, they can be determined on the basis of benchmark values, provided an appropriate database is available. Since this is not always possible, estimates of the cost of equity for various production technologies are being used.

The cost of capital is expressed in various ways - usually as the weighted average cost of capital or the so-called hurdle rate (the minimum rate of return), expressed in real terms before tax (e.g. Frontier Economics 2010; Redpoint 2010; Oxera 2011; DECC 2011). However, it should be noted that the cost of equity, obtained from the CAPM model, is usually the post-tax rate in nominal terms; therefore, depending on the needs, the appropriate values should be recalculated*

\footnotetext{
* A large number of analysts use simple conversion of one value to another based on a simple mathematical formula: pre-tax rate $=$ post-tax rate $/(1-$ tax rate), but this method is often criticized (Lonergan 2009; Davis 2010).
} 
The article presents the values of interest rates in the latter view. The analysis was carried out using data provided by Damodaran (Damodaran Online 2018) and Hern et al. (2015). It should be noted that the energy companies on Damodaran pages (Damodaran Online 2018) are listed arbitrarily, making it difficult to carry out a detailed analysis. This is due to the fact that modern enterprises are highly diversified and often operating in different markets.

In the years 2001-2017, the nominal risk-free rate, calculated on the basis of return rates on long-term US securities, varied from $5 \%$ in 2001 to $1.76 \%$ in 2012, with an average of $3.32 \%$ (Damodaran Online 2018). The company-specific risk, measured by the beta coefficient, changed over time just like in the case of the risk-free rate. Analyses carried out for energy companies on the North American market indicate that from the beginning of the century to today, the average beta for the sector has changed in a very wide range, showing a downward trend (Fig. 1). Up until the first decade of the 21 st century, the value of companies' shares was more volatile (risky) than the market ( $>2$ ) in 2005-2006, which was, among others, a consequence of the loss of investors' confidence in energy sector companies due to the collapse of Enron. In 2013, the beta of the sector reached the value below 1 for the very first time; a further decline, to a value of 0.5 in 2017, was observed in the following years. Such a significant decrease in the value of the coefficient (and therefore the risk) results mainly from the fact that Damodaran* decided to

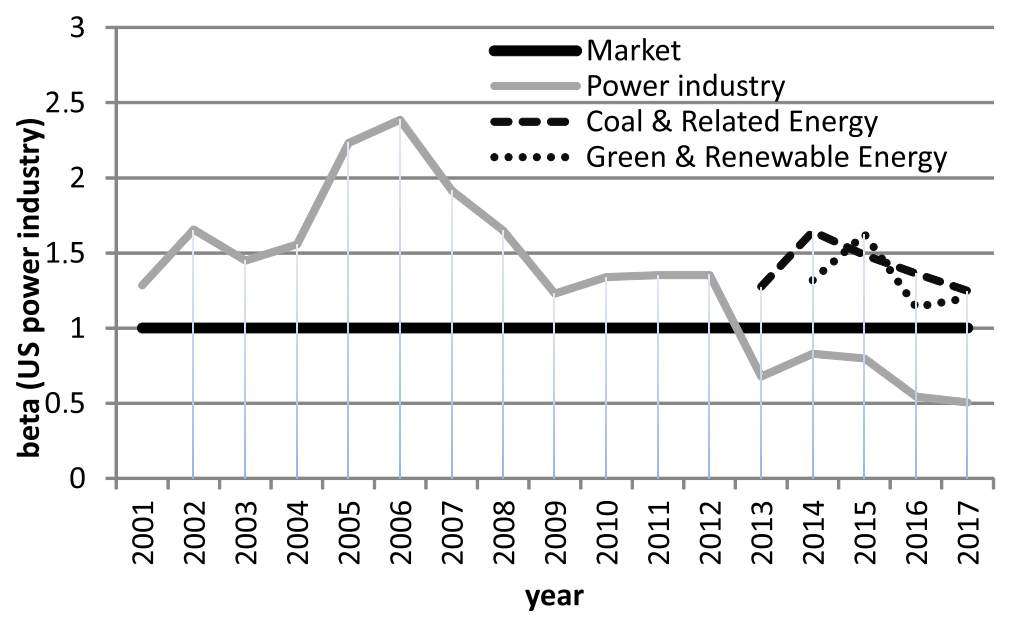

Fig. 1. The beta coefficients of the US energy industry from 2013-2017 (based on Damodaran Online 2018)

Rys. 1. Współczynniki beta amerykańskiego przemysłu energetycznego

\footnotetext{
* When it comes to Damodaran pages, the "Power" category included all manufacturing technologies up until the years 2013-14. In 2014, due to the development of renewable energy technologies, the "Green \& Renewable Energy" category was determined, while the category of companies producing coal (acronym: "Coal") was expanded a year earlier to include a number of generating units using this fuel. As a result, the category name was changed to "Coal \& Related Energy"; however, it should be borne in mind that it mainly includes enterprises with a dominant share of mining production.
} 
exclude the group of renewable energy companies, whose shares were perceived as riskier than the market (average beta in 2014-2017 - 1.32), from the sector in 2014. The sectoral causes include the shale revolution and the efficiency of the energy industry's actions towards regaining the confidence of investors and lenders.

Such behavior of the beta coefficient (and risk-free rates) has resulted in changes in the average cost of capital calculated for the sector (Fig. 2). In the years 2001-2017 the average level of this rate amounted to $10.21 \%$. In the critical years 2005-2006, the discussed cost was over $15 \%$, which can be compared with the risk associated with geological and mining projects (base metal mining) at the pre-investment stage. In 2008, the RADR fell below $10 \%$ for the first time - it is currently at the level of $5 \%$. This means that investments in conventional energy in the United States are currently safe - the "risk-adjusted" discount rate is only slightly more than twice the risk-free rate. A different situation occurs in the renewable energy subsector; due to the risk associated with these technologies (mainly: technological immaturity vs. high capital costs), investors expect rates of return significantly exceeding $8 \%$.

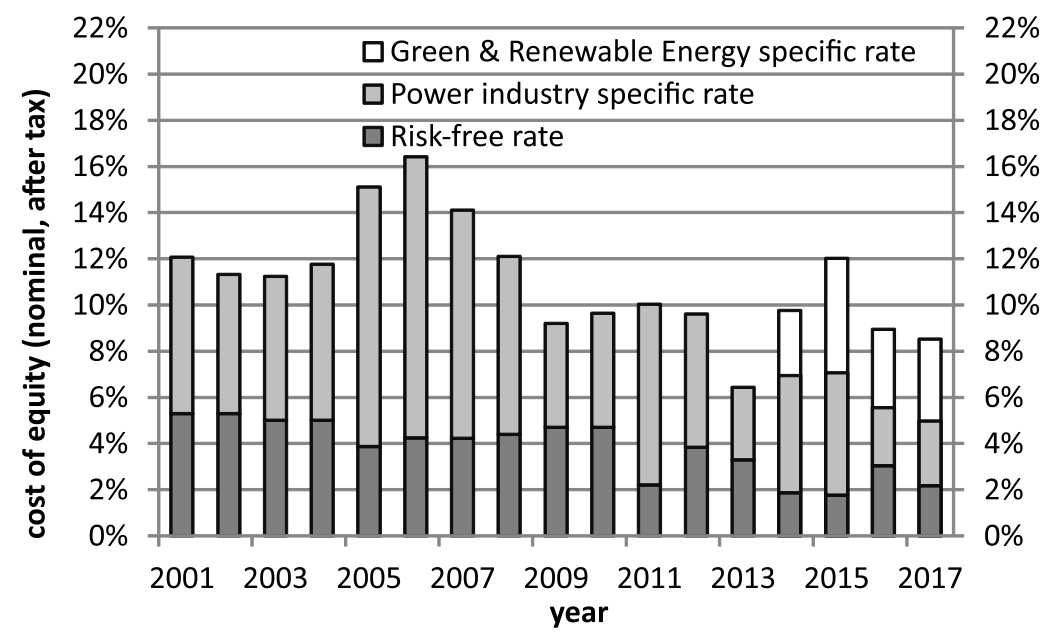

Fig. 2. The cost of equity (nominal after tax) for energy companies in Europe in the years 2013-17 Caution: The risk associated with the specificity of technology for the „Green \& Renewable Energy” category in the years 2014-2017 is indicated in columns highlighted in gray and white (based on Damodaran Online 2018)

Rys. 2. Koszt kapitału własnego (nominalny, po uwzględnieniu opodatkowania) przedsiębiorstw energetycznych USA Uwaga! Ryzyko związane ze specyfiką technologii dla kategorii „Green \& Renewable Energy” w latach 2014-2017 obejmuje na rysunku części kolumn wypełnione kolorem szarym i białym

Damodaran Online provides data for Europe (as well as for Japan and emerging markets and the World) since 2013. Based on the analysis of beta coefficients of the energy industry subsectors, it should be stated that investing in conventional energy ("Power") is generally more risky in Europe than in the United States (Fig. 3). The beta of this industry, with the average of 1.05 
(the lowest value: 0.95 was recorded in 2015, while the highest: 1.13 - in 2017), oscillates within the limits of the beta market. In turn, investments in renewable technologies are less risky than in the US; this is due to the European Union's climate policy. The average beta of this subsector in the region (2014-2017) is at 1.14. In the analyzed period of the last five years, the most variable beta values can be observed in the case of enterprises in the "Coal \& Related Energy" category - the extreme values of the range are: 0.72 in 2016 and 1.61 in the year 2014, with an average of 1.09. Therefore, investments in European companies from this sector are very risky. This is a different situation compared to global averages (Fig. 4) - beta for this group of companies is more stable ( $>$; 1 each year); for renewable energy enterprises, the discussed coefficient behaves similarly, but in the case conventional energy enterprises it is, unlike in Europe, lower $(<; 1$ in all the years analyzed).

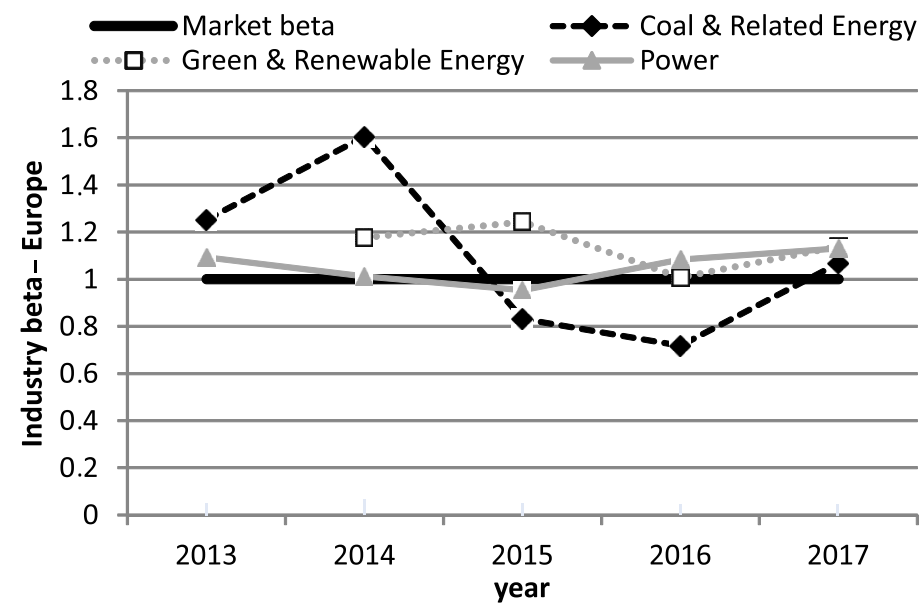

Fig. 3. The beta coefficients of the European energy industry from 2013-2017 (based on Damodaran Online 2018)

Rys. 3. Współczynniki beta europejskiego przemysłu energetycznego w latach 2013-2017

The beta coefficient levels translate into the cost of equity - in 2017, for all sub-sectors of the industry, this cost was similar in Europe (Fig. 5); the average level of these rates are slightly variable, ranging from $10 \%$ in the renewable enterprises group, through $9.7 \%$ for "Coal \& $\mathrm{Re}$ lated Energy", up to $9.44 \%$ for conventional energy enterprises. When analyzing the worldwide average risk adjusted discount rate, certain regularity can be observed: the highest cost of equity is associated with enterprises from the "Coal \& Related Energy" category - $11.27 \%$ between 2013-2017, followed by renewable technologies category $-10.22 \%$ in the years $2014-2017$, while the lowest cost of equity is associated with the "Power" category $-8.50 \%$. This means that the lowest investment risk is associated with the latter companies, using mostly traditional technologies. The calculated average risk adjusted discount rate (RADR) can be compared with similar rates obtained for several other industries: the integrated oil and gas sector ("Oil/gas (in- 
tegrated)"- the world average in the period 2013-2017 of 12.31\%, base metal mining ("Metals \& mining" $-12.11 \%$ ), or precious metal mining ("Precious metals" - 11.80\%) (own work based on Damodaran Online 2018).

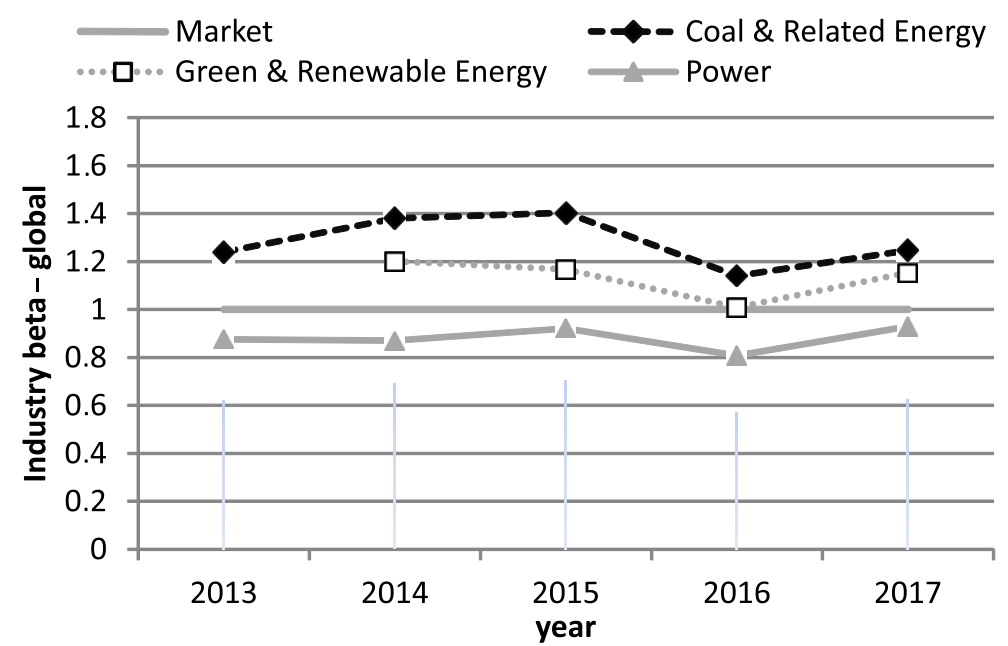

Fig. 4. The beta coefficients of the energy industry worldwide from 2013-2017 (based on Damodaran Online 2018)

Rys. 4. Współczynniki beta przemysłu energetycznego w latach 2013-2017 - świat

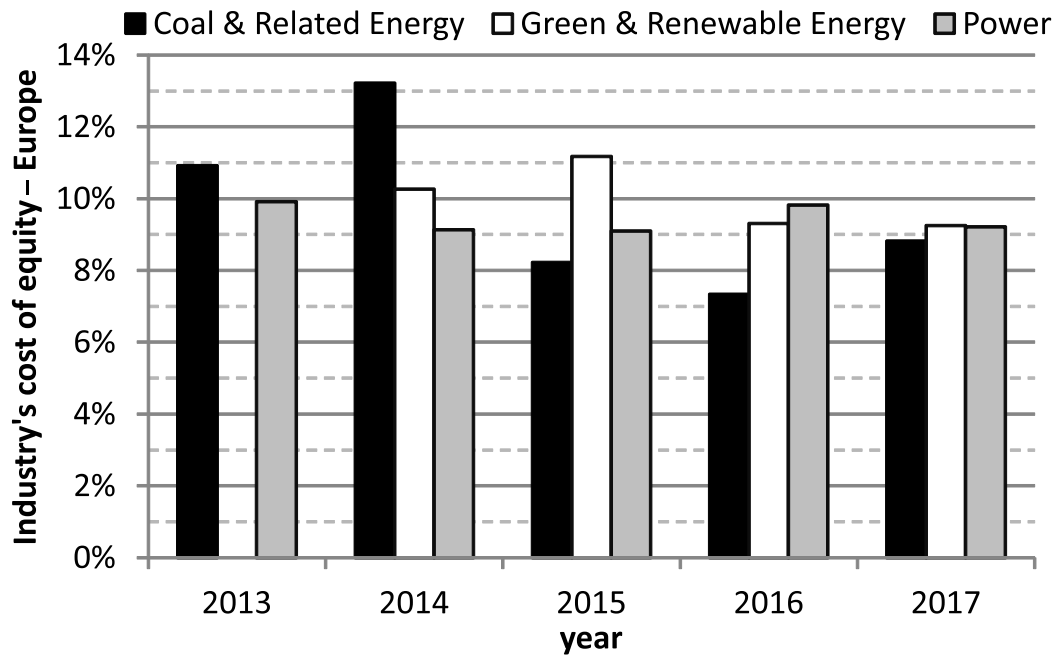

Fig. 5. The cost of equity (nominal after tax) for energy companies in Europe in the years 2013-2017 (based on Damodaran Online 2018)

Rys. 5. Koszt kapitału własnego (nominalny, po uwzględnieniu opodatkowania) przedsiębiorstw energetycznych Europy w latach 2013-2017 
It is interesting to compare the values obtained for Europe with the threshold levels set by Hern et al. (2015) for each technology under UK market conditions in 2015 (Table 2, Fig. 6). The discussed values are similar. It has been confirmed that investors perceive investments in new technologies as risky.

TABLE 2. Threshold rates (nominal net of tax) for manufacturing technologies in three scenarios, according to NERA, 2015 (Hern et al. 2015)

TABELA 2. Stopy progowe (nominalne, po odliczeniu podatku) dla technologii wytwarzania w trzech scenariuszach według spółki NERA, $2015 \mathrm{r}$.

\begin{tabular}{|l|c|c|c|}
\hline \multicolumn{1}{|c|}{ Technology } & $\begin{array}{c}\text { Low } \\
\text { scenario }\end{array}$ & Reference scenario & $\begin{array}{c}\text { High } \\
\text { scenario }\end{array}$ \\
\hline Hydropower & $6.80 \%$ & $8.40 \%$ & $10.00 \%$ \\
\hline Solar PV & $7.60 \%$ & $8.90 \%$ & $10.20 \%$ \\
\hline Onshore Wind & $7.30 \%$ & $9.20 \%$ & $11.10 \%$ \\
\hline Gas plants & $8.30 \%$ & $9.90 \%$ & $11.52 \%$ \\
\hline Coal plants & $8.30 \%$ & $9.90 \%$ & $11.50 \%$ \\
\hline Waste (other) & $8.78 \%$ & $10.15 \%$ & $11.78 \%$ \\
\hline Nuclear & $9.50 \%$ & $11.10 \%$ & $12.70 \%$ \\
\hline Biomass & $9.72 \%$ & $11.16 \%$ & $12.64 \%$ \\
\hline Geothermal & $9.75 \%$ & $11.30 \%$ & $12.95 \%$ \\
\hline Tidal Stream & $10.25 \%$ & $11.80 \%$ & $13.40 \%$ \\
\hline Wave & $10.50 \%$ & $12.00 \%$ & $13.60 \%$ \\
\hline CCS & $10.57 \%$ & $12.10 \%$ & $13.73 \%$ \\
\hline Offshore Wind & $10.39 \%$ & $12.19 \%$ & $13.94 \%$ \\
\hline
\end{tabular}

\section{Conclusions}

The size of the investment risk in the power industry is a reflection of the sources and scale of the basic types of uncertainty in the various phases of its development. These phases include multistage pre-realization studies, feasibility studies, construction, production, closure, and reclamation. The economic assessment of the project requires a complete understanding of the accompanying risks and consequences, along with the probabilities of their occurrence. It should be emphasized that determining the level of risk in the energy sector is an extremely complex problem. An important role is also played by regulatory and legal risks and costs related to broadly understood environmental protection. Optimal forecasts and indicators of costs and 
benefits resulting from climate policy and environmental protection are often difficult to access or extremely unreliable. Therefore, it is not easy to include them in a conventional cash flow analysis since it is impossible to have accurate information about the actual parameters for the entire lifetime of the project.

In the case of a commonly used method for assessing the economic efficiency of investments, the DCF (discounted cash flow) analysis, the only parameter reflecting the risk of a project is the discounting parameter. The higher the risk, the greater the rate used by both analysts and investors. In the DCF analysis, this most often occurs in the form of the weighted average cost of capital (WACC), which is the rate "weighing" the cost of investors' equity and the cost of debt. The first component, also referred to as the risk-adjusted discount rate (RADR), is a good indicator for risk comparisons between different projects.

In the presented paper, the average values of the cost of capital of enterprises from individual subsectors of the energy sector in the US, Europe, and worldwide were subjected to an analysis. This allowed interesting results to be obtained. They confirm that investments in advanced renewable energy technologies are the most risky; the least risky, in turn, is the allocation of equity capital to hydropower, proven solar technologies, wind farms, and traditional sources (coal, gas). It should be noted that a reliable analysis of the cost of equity is hindered by the fact that it is determined for highly diversified companies (not projects), and therefore it is difficult to precisely determine it for each technology; therefore, some issues raised in the article require a broader approach and further research. However, the presented results may provide a relatively good benchmark for investors and analysts engaged in the evaluation of investments in the sector.

\section{References}

BARTNIK, P. 2008. Technical and economic efficiency calculation in professional power engineering ( $R a-$ chunek efektywności techniczno-ekonomicznej w energetyce zawodowej). Publishing House of the Opole University of Technology, Opole, 242 pp. (in Polish).

Copeland et al. 1997 - Copeland, T., Koller, T. and Murrin, J. 1997. Valuation: Measuring and Managing the Value of Companies. WIG-Press, Warsaw, $516 \mathrm{pp}$.

Damodaran Online, 2018 - Data. Costs of Capital by Industry (US, Europe, Global). Website of Aswath Damodaran, [Online] pages.stern.nyu.edu/ adamodar/ [Accessed: 2018-07-15].

DAVIS, K. 2010. Why Pre-Tax Discount Rates Should be Avoided. The Journal of Applied Research in Accounting and Finance Vol. 5, Iss. 2, pp. 2-5.

DECC, 2011 - Review of the Generation Costs and Deployment Potential of Renewable Electricity Technologies in the UK, Study Report, Department of Energy \& Climate Change, London, REP001, Ove Arup $\&$ Partners Ltd, Job No 215030, October, 295 pp.

DECC, 2013 - Electricity Generation Costs 2013. Department of Energy \& Climate Change, London, $13 \mathrm{D} / 185,67 \mathrm{pp}$.

ERO, 2015 - A method for the calculation of return on capital employed for Distribution System Operators in the years 2016-2020 (Metoda określania wskaźnika zwrotu kosztu zaangażowanego kapitału dla operatorów systemów elektroenergetycznych na lata 2016-2020). The Energy Regulatory Office, Warsaw, 10 pp. (in Polish). 
Frontier Economics, 2010 - NERSA's Tax Treatment of the Risk-Free Rate when Applying the CAPM, A Note Prepared for Transnet Pipelines, Frontier Economics Ltd, September, 8 pp.

Grant Thornton, 2018 - Renewable Energy Discount Rate Survey Results - 2017. Grant Thornton and Clean Energy Pipeline Initiative, Grant Thornton UK LLP, 26 pp.

Hern et al. 2015 - Hern, R., Radov, D., CARmel, A., Spasovska, M. and GuO, J. 2015. Electricity Generation Costs and Hurdle Rates. Lot 1: Hurdle Rates update for Generation Technologies, Report Prepared for the Department of Energy and Climate Change (DECC), NERA Economic Consulting, London, July, $102 \mathrm{pp}$.

Lonergan, W. 2009. Pre and Post Tax Discount Rates and Cash Flows - A Technical Note. The Journal of Applied Research in Accounting and Finance Vol. 4, Iss. 1, pp. 41-45.

MAYO, H.B. 1997. Investments: An Introduction. Warsaw: Wydawnictwo K.E. Liber, 909 pp.

[Online] https://bip.ure.gov.pl/download/3/3026/WACC20112015zalacznikdozalozen.pdf [Accessed: 2018-07-02].

Oxera, 2011 - Discount Rates for Low-Carbon and Renewable Generation Technologies, Report prepared for the Committee on Climate Change, Oxera Consulting Ltd, April, Oxford-Brussels, p. 46.

PINDRED, R.J. 1995. (Mis)use of Monte Carlo Simulations in NPV Analysis - Discussion. Mining Engineering 47(12), pp. 861-862.

Redpoint, 2010 - Electricity Market Reform Analysis of Policy Options, A Report by Redpoint Energy in Association with Trilemma UK. Version 1.0, 15/12/10, Redpoint Energy Ltd, 141 pp.

Stenibach, J. and StaniaszeK, D. 2015. Discount Rates in Energy System Analysis, Discussion Paper, BPIE, Fraunhofer ISI, pp. 17, [Online] http://bpie.eu/uploads/lib/document/attachment/142/Discount rates_in_energy_system-discussion_paper_2015_ISI_BPIE.pdf [Accessed: 2018-07-02].

ZAMASZ, K. 2015. Economic efficiency of an electricity undertaking in the context of capacity market introduction (Efektywność ekonomiczna przedsiębiorstwa energetycznego w warunkach wprowadzenia rynku mocy). PWN, Warsaw, 196 pp. (in Polish).

Zamasz, K. 2017. Discount Rates for the Evaluation of Energy Projects - Rules and Problems, Scientific Papers of Silesian University of Technology, Organization and Management Series, issue 101 No. 1974, pp. 571-583.

\section{Koszt kapitału własnego przedsięwzięć inwestycyjnych w energetyce}

\section{Streszczenie}

Istotny wpływ na wartość przedsięwzięć inwestycyjnych ma uwzględnienie wpływu czynnika czasu i ryzyka. Inwestycje w energetyce są projektami długoterminowymi i już jako takie obarczone są niepewnością, związaną z wieloletnim zamrożeniem kapitału i uzyskaniem oczekiwanego zwrotu. W energetyce niepewność tę zwiększają czynniki specyficzne charakterystyczne dla sektora, w tym w szczególności 
zmiany otoczenia polityczno-prawnego i szybkiego postępu technicznego. W stosowanej powszechnie do oceny efektywności ekonomicznej inwestycji - analizie zdyskontowanych przepływów pieniężnych ( $d i$ scounted cash flow, DCF) - jedynym parametrem wyrażającym niepewność inwestorów w zakresie realizacji inwestycji jest stopa dyskontowa - tym większa, im większe ryzyko przedsięwzięcia. Decyduje ona o wartości bieżącej projektu stając się tym samym istotnym kryterium oddziałującym na decyzje inwestorów. $Z$ tego powodu jej dobór ma doniosłe znaczenie dla oceny efektywności inwestycji. Stopa ta, występując zwykle w postaci średnioważonego kosztu kapitału, WACC - obejmuje zasadniczo dwa elementy: koszt kapitału własnego oraz obcego. Ze względu na różną relację tych dwóch źródeł w finansowaniu projektów przeprowadzanie analiz WACC $\mathrm{w}$ celu porównywania ryzyka związanego z różnymi technologiami jest nie do końca czytelne. Dobrym rozwiązaniem problemu jest stosowanie jako wskaźnika kosztu kapitału własnego. Niniejszy artykuł obejmuje analizy tego kosztu jako miernika ryzyka związanego inwestycjami energetycznymi w Stanach Zjednoczonych, Europie i świecie.

SŁOWA KLUCZOWE: inwestycje w energetyce, ryzyko, koszt kapitału własnego, stopa dyskontowa dostosowana do ryzyka 